\title{
Strategi Pengembangan Kewirausahaan Sosial PT Bina Swadaya Konsultan
}

\author{
Social Entrepreneurship Development Strategy PT Bina Swadaya Konsultan
}

Ikhwan Safa'at ${ }^{1^{*}}$, Rizal Syarief $^{2 \sharp}$ dan Ani Suryani ${ }^{3 \sharp}$

${ }^{1}$ PT Bina Swadaya Konsultan, Jakarta

${ }^{2}$ Departemen Ilmu dan Teknologi Pangan, Fakultas Teknologi Pertanian, Institut Pertanian Bogor

${ }^{3}$ Departemen Teknologi Industri Pertanian, Fakultas Teknologi Pertanian, Institut Pertanian Bogor

\#Jl. Kamper, Kampus IPB Darmaga, Bogor 16680

\begin{abstract}
ABSTRAK
Dalam World Entrepreneurship Forum yang kedua di Lyon, Perancis tahun 2009, Bina Swadaya menyatakan definisi Social Entrepreneurship adalah pembangunan sosial dengan solusi kewirausahaan. Pembangunan sosial merujuk Social Development Summit merupakan upaya pembangunan yang mencakup aspek pemberantasan kemiskinan, penciptaan lapangan kerja produktif dan integrasi sosial. PT Bina Swadaya Konsultan, anak perusahaan Bina Swadaya dengan spirit entrepreneurship melakukan keberlanjutan proses pemberdayaan masyarakat yang mampu memberikan manfaat bagi masyarakat dan life-cycle perusahaan mengembangkan kewirausahaan sosial sesuai kompetensi perusahaan. Tujuan kajian adalah (1) Mengidentifikasi faktor-faktor internal dan eksternal perusahaan yang berpengaruh terhadap pengembangan kewirausahaan sosial PT BSK, (2) Mendapatkan alternatif-alternatif strategi dalam pengembangan kewirausahaan sosial sesuai tujuan dari pengembangan kewirausahaan sosial, (3) Mendapatkan prioritas strategi pengembangan kewirausahaan sosial yang sesuai dengan kondisi internal dan eksternal perusahaan. Metode yang digunakan adalah IFE (Internal Factor Evaluation), EFE (External Factor Evaluation), IE Matrix (Internal External Matrix), SWOT (Strengths, Weaknesses, Opportunities, Threats) and QSPM (Quantitative Strategic Planning Matrix). Dari hasil kajian didapatkan prioritas strategi pengembangan kewirausahaan sosial PT. BSK adalah (1) Re-strukturisasi dan Rekayasa Ulang, (2) Fokus, Pengembangan Produkdan Differensiasi, (3) Pengembangan Pasar dan Penetrasi Pasar, (4) Integrasi Vertikal, (5) Peningkatan Produk dan Diversifikasi.
\end{abstract}

Kata kunci: Bina Swadaya konsultan, kewirausahaan sosial, strategi

\section{ABSTRACT}

In the second World Entrepreneurship Forum in Lyon, France in 2009, Bina Swadaya stated definition of Social Entrepreneurship is social development with entrepreneurship solution. Developments that includes aspects of poverty alleviation, productive employment and social integration. PT Bina Swadaya Konsultan, a subsidiary of Bina Swadaya Organization with the spirit of entrepreneurship in an effort to sustain the community development process that can provide benefits for society and the life-cycle companies develop social entrepreneurship in accordance with its competence. . The purpose of this study was (1) Identify the internal and external factors that influence the development of social entrepreneurship PT BSK, (2) Getting some alternatives strategy in the development of social entrepreneurship to the purpose of the development of social entrepreneurship, (3) Obtain the priority of social entrepreneurship development strategy in accordance with the company's internal and external conditions. Research methodology using IFE, EFE, IE Matrix, SWOT and QSPM. Priority strategy of development of social entrepreneurship PT BSK are (1) Restructuring and Market Penetration, (2) Focus, Product Development and Differensiation, (3) Market Development and Market Penetration, (4) Vertical Integration, (5) Product Improvement and Diversification.

Key words: Bina Swadaya consultant, social entrepreneurship, strategy

Korespondensi:

*) PT Bina Swadaya Kosultan. Jl. Gunung Sahari 3 No. 25, Jakarta Pusat; e-mail: ichone_s@yahoo.com 


\section{PENDAHULUAN}

Istilah kewirausahaan sosial atau social entrepreneurship dalam beberapa tahun terakhir ini menjadi bahan yang diperbincangkan dikalangan pengusaha dan juga lembaga sosial, bahkan pemerintah. Kewirausahaan sosial menjadi fenomena baru dalam pergerakan perubahan sosial. Istilah social entrepreneurship atau kewirausahaan sosial digunakan pertama dalam literatur tentang perubahan sosial pada tahun 1960-an dan 1970-an. Istilah mulai digunakan secara luas pada tahun 1980-an dan 1990-an, dipromosikan oleh Drayton pendiri Ashoka dan Leadbeater, serta tokoh lainnya seperti Young, seorang promotor "social enterprise" terkemuka sebagai pengusaha paling sukses di dunia sosial, karena perannya dalam menciptakan lebih dari enam puluh organisasi baru di seluruh dunia, termasuk sekolah pengusaha sosial yang ada di Inggris, Australia dan Kanada dari tahun 1950 hingga 1990-an. Di Amerika dikenal Schramm (2003), di Afrika Selatan dikenal Khosa (1990), di Brasil dikenal Rosa (1988), di Bangladesh dikenal Yunus (1983) dan banyak yang lainnya (Bornstein, 2004).

Entrepreneurial intention atau niat kewirausahaan dapat diartikan sebagai langkah awal dari suatu proses pendirian sebuah usaha yang umumnya bersifat jangka panjang (Lee \& Wong, 2004). Menurut Krueger (1993), niat kewirausahaan mencerminkan komitmen seseorang untuk memulai usaha baru dan merupakan isu sentral yang perlu diperhatikan dalam memahami proses kewirausahaan pendirian usaha baru.

Social Entrepreneurship sebagai suatu kerangka berfikir yang berarti kegiatan-kegiatan yang menciptakan kemakmuran bukan hanya untuk perorangan atau keluarga akan tetapi melibatkan suatu wilayah tertentu dan masyarakat banyak serta masyarakat terpinggirkan. Kegiatan dilakukan secara bersama dalam rangka memperbaiki nasibnya dengan pola pikir kolaboratif, kooperatif dan mekanisme pembagian kemakmuran (Decanay, 2002). Bina Swadaya mengartikan kewirausahaan sosial sesuai dengan kondisi dan perkembangan iklim masyarakat, politik serta usaha di Indonesia. Dalam World Entrepreneurship Forum yang kedua di Lyon, Perancis tahun 2009, Bina Swadaya menyatakan definisi Social Entrepreneurship adalah pembangunan sosial dengan solusi kewirausahaan. Pembangunan sosial yang dimaksud merujuk Social Development Summit (Kopenhagen, 1996) merupakan upaya pembangunan yang mencakup aspek pemberantasan kemiskinan, penciptaan lapangan kerja produktif dan integrasi sosial (Ismawan, 2010). Menurut Tan et al. (2005), kewirausahaan sosial biasa disebut pengembangan masyarakat atau organisasi bertujuan sosial.

PT Bina Swadaya Konsultan (BSK) merupakan salah satu perusahaan di bawah Yayasan Bina Swadaya (YBS) yang melakukan kegiatan konsultasi pemberdayaan masyarakat sejak tahun 1983. Kegiatan PT BSK adalah memberikan layanan terhadap masyarakat, khususnya bagi masyarakat terpinggirkan bekerjasama dengan pihak pemerintah, lembaga internasional dan juga perusahaan-perusanaan swasta selaku penyandang dana kegiatan melalui program-program livelihood, lingkungan, kesehatan, pendidikan dan pengurangan risiko bencana atau DRR (Disaster Risk Reduction).

Dalam perkembangannya, PT BSK dengan spirit entrepreneurship sebagai upaya untuk keberlanjutan proses pemberdayaan masyarakat yang mampu memberikan manfaat bagi masyarakat dan siklus hidup perusahaan, mengembangkan kewirausahaan sosial sesuai dengan kompetensi perusahaannya. Atas dasar tersebut, diperlukan strategi yang tepat untuk mewujudkan tujuan tersebut sesuai dengan konsep dan visi misi lembaga.

Tujuan dari kajian adalah (1) Mengidentifikasi faktor-faktor internal dan eksternal perusahaan yang berpengaruh terhadap pengembangan kewirausahaan sosial PT BSK, (2) Mendapatkan alternatif-alternatif strategi dalam pengembangan kewirausahaan sosial sesuai tujuan dari pengembangan kewirausahaan sosial dan (3) Menyusun prioritas strategi pengembangan kewirausahaan sosial yang sesuai dengan kondisi internal dan eksternal perusahaan.

\section{METODOLOGI}

Penelitian dilakukan di PT Bina Swadaya Konsultan, Jakarta Pusat pada bulan Juni 2013 hingga Desember 2013. Metode dalam melakukan perumusan strategi dapat dipadukan menjadi kerangka kerja pembuatan keputusan yang dilakukan secara bertahap. Proses manajemen strategis terdiri dari tiga tahapan utama yaitu perumusan strategi, implementasi strategi serta evaluasi dan pengendalian strategi yang diawali dengan pengamatan lingkungan (Hubeis, 2008). Untuk mengenali, mengevaluasi dan memilih 
strategi, dapat dilakukan melalui tiga tahap sebagai berikut:

1. Tahap pertama (tahap input), yaitu meringkas informasi input dasar yang diperlukan untuk merumuskan strategi terdiri dari IFE (Internal Factor Evaluation), EFE (External Factor Evaluation) dan IE Matrix (Internal External Matrix).

2. Tahap kedua (tahap pencocokan), yaitu memfokuskan pada menghasilkan strategi alternatif yang layak dengan memadukan faktor-faktor eksternal dan internal dengan menggunakan matriks SWOT (Strengths, Weaknesses, Opportunities, Threats)

3. Tahap ketiga (tahap keputusan), yaitu pengambilan keputusan dengan menggunakan teknik Quantitative Strategic Planing Matrix (QSPM). Teknik ini menggunakan informasi input dari tahap 1 untuk mengevaluasi strategi alternatif layak, yang diidentifikasi pada tahap 2. QSPM mengungkapkan daya tarik relatif dari strategi alternatif dan menjadi dasar untuk memilih strategi spesifik.

Pengumpulan data dilakukan dengan metode wawancara, kuesioner, FGD (Focus Group Discussion) dan studi pustaka. Tahap pengumpulan data yang diperloleh dari data sekunder maupun primer hasil wawancara dan kuesioner dilakukan analisis deskriptif untuk mendapatkan informasi lebih mendalam tentang objek penelitian (Rangkuti, 2005).

Internal Factor Evaluation (IFE) digunakan untuk mengetahui faktor-faktor internal perusahaan berkaitan dengan kekuatan dan kelemahan yang dianggap penting. External Factor Evaluation (EFE) untuk mengevaluasi faktor-faktor eksternal organisasi. (David, 2004).

Matriks SWOT untuk mendapatkan alternatif strategi yang dapat diterapkan dan QSPM untuk mengevaluasi strategi alternatif secara objektif berdasarkan pada faktor-faktor kritis internal dan eksternal yang dikenali sebelumnya (David, 2004).

\section{HASIL DAN PEMBAHASAN}

\section{Internal Factor Evaluation}

Dari analisis yang dilakukan didapatkan faktor-faktor dominan yang berpengaruh terhadap pengembangan kewirausahaan sosial PT BSK untuk faktor internal adalah Spirit lembaga $(0,311)$, anggaran $(0,305)$, visi $(0,280)$, misi $(0,278)$, konsep $(0,262)$, kebijakan $(0,248)$, struktur organi- sasi $(0,235)$, Alokasi dan kualitas $\operatorname{SDM}(0,228)$, pengendalian $(0,213)$ dan alat ukur dampak sosial $(0,208)$.

Spirit lembaga dalam membanguan kewirausahaan sosial (KS) adalah jujur, people enggament, profit berkeadilan, ramah lingkungan dan pembangunan local Champion di berbagai daerah. Anggaran dinilai menjadi kekuatan dikarenakan perusahaan telah menyediakan anggaran khusus untuk pelaksanaan KS. Visi dari unit kewirausahaan sosial adalah menjadi connector keberlanjutan small bussines masyarakat di Indonesia dalam rangka membangun spirit solidaritas ekonomi di Indonesia. Hal ini diputuskan dalam rangka membangun keberlanjutan bisnis masyarakat yang memiliki keterbatasan atas kemampuan dan juga akses. Konsep yang dimaksud adalah komitmen bersama dalam mengusung pembangunan sosial melalui kewirausahaan meliputi pemberantasan kemiskinan, penciptaan lapangan kerja dan integrasi sosial. Misi dari PT BSK dalam mengembangkan kewirausahaan sosial yang selanjutnya menjadi misi dari unit kewirausahaan sosial itu sendiri adalah menyebarluaskan spirit entrepreneurship dalam membangun bisnis yang jujur, membangun solidaritas usaha guna mendukung supply chain produksi dan pemasaran di level masyarakat, menciptakan sumber-sumber pendapatan yang halal secara independen dan berkelanjutan, meningkatkan margin bagi para pelaku usaha mikro sampai masyarakat marginal, memastikan keberlanjutan paska proyek yang mengarah kepada model bisnis yang terintegrasi. Kebijakan yang dimaksud adalah aturan-aturan yang ditetapkan manajemen dalam rangka pencapaian misi dari KS. Kebijakan mengacu kepada hal spesifik, metode, prosedur, aturan, formulir, dan praktik administrasi yang dibuat untuk mendukung dan mendorong pekerjaan melalui tujuan yang telah ditetapkan. Karena pengembangan KS masih dalam proses awal maka masih diperlukan kebijakan lebih lanjut tentang pengaturan pelaksanaan kegiatan KS. Struktur Organisasi, semakin berkembangkanya kegiatan KS maka diperlukan pengembangan struktur yang sesuai dengan kegiatan yang dilakukan. Alokasi sumber daya manusia (SDM) dan mutu SDM diperlukan mengikuti struktur yang dibutuhkan dalam pengembangan KS. Alat ukur dampak sosial merupakan salah satu alat untuk menilai kinerja pengembangan KS. Semakin besar dampak yang dihasilkan terhadap masyarakat maka semakin baik perkembangan pelaksanaannya. Untuk 
kepentingan tersebut maka diperlukan adanya alat ukur yang saat ini masih dalam proses perumusan.

\section{External Factor Evaluation}

Dari analisis yang dilakukan, didapatkan faktor eksternal dominan adalah prospek $(0,302)$, nilai produk $(0,272)$, mitra kerja $(0,261)$, sarana produksi mitra kerja $(0,254)$, jaringan pasar $(0,253)$, lokasi perusahaan $(0,244)$, penerimaan konsumen atau kualitas produk $(0,239)$, produk pesaing $(0,235)$, perusahaan pesaing $(0,235)$, kontinuitas bahan baku $(0,190)$.

Prospek adalah kemungkinaan pengembangan kegiatan di masa yang akan datang. Hal ini dinilai bagi $\mathrm{KS}$ akan berpeluang besar untuk bisa berkembang dikarenakan kegiatan dibangun bersama masyarakat disertai dengan peningkatan kemampuan dan peningkatan akses, baik akses terhadap permodalan, keterampilan maupun pemasaran. Dengan pola yang direncanakan dibangun bersama masyarakat maka peluang ini dimungkinkan akan lebih bisa diterima kedepannya. Menurut Priyanto (2009), perkembangan yang pesat dari teknologi komunikasi, produksi dan jasa juga sangat berperan pada seseorang sehingga akan memotivasi atau tidak seseorang dalam hidupnya. Peubah eksternal ini terus berubah dan menyebabkan kewirausahaan seseorang juga terus berubah dengan intensitas dan kompleksitas yang tidak konstan.

Nilai Produk yang dimaksud adalah nilai yang melekat pada produk yang dihasilkan baik dari segi visual, rasa, bobot, khasiat maupun keunikan dari produk tersebut. Produk yang dihasilkan saat ini memiliki karakteristik masingmasing daerah mitra kerja yang dinilai berpotensi untuk dikembangkan dan memiliki daya saing. Mitra Kerja adalah lembaga, institusi, kelompok masyarakat dan masyarakat yang bekerja sama dengan PT BSK dalam mengembangkan produk. Mitra kerja kerja yang dimiliki oleh PT BSK tersebar di berbagai wilayah sesuai wilayah dampingan dari PT BSK. Hal ini dinilai menjadi peluang dalam pengembangan KS PT BSK. Sarana Produksi Mitra Kerja. Pengembangan kegiatan tidak dimulai dari nol. Hal ini karenakan sistem kerja sama yang dibangun dengan mitra kerja. Dipastikan mitra kerja telah memiliki setidaknya sebagian kecil sarana dan prasarana produksi dan juga pemasaran. Dampaknya PT BSK tidak perlu mengeluarkan anggaran terlalu besar dalam pengadaan alat produksi sehingga perusahaan dapat lebih efektif dan efisien. Jaringan Pasar yang dimiliki berdasarkan pengalaman pemberdayaan yang telah dilakukan cukup lama menjadikan hal tersebut peluang yang sangat potensial dalam pengembangan KS. Lokasi Perusahaan yang terletak di Jakarta dan Yogjakarta dinilai menjadi kelebihan dan juga kekurangan dalam pengembangan KS dikarenakan posisi mitra yang sebagian berlokasi di luar pulau jawa. Hal ini menjadi tantangan dalam pengembangan. Kualitas produk saat ini masih belum stabil dan ini menjadi tantangan ke depan terutama dalam menghadapi persaingan dengan perusahaan sejenis lainnya. Perusahaan dan produk pesaing tentunya akan menjadi ancaman dalam pengembangan terutama dalam lokasi dimana sasaran pasarnya sama. Kontinuitas bahan baku. Pada umumnya produk yang dihasilkan berbahan baku dari hasil pertanian. Biasanya produk pertanian memiliki ketergantungan dengan musim. Oleh karenanya perlu dilakukan antisipasi kelangkaan bahan baku dalam menjaga ketersediaan produk di pasaran.

\section{Internal External Matrix}

Berdasarkan analisis matrik IE bahwa pengembangan Kewirausahaan sosial berada pada kuadran 5 . Hal ini berarti perusahaan dalam posisi pelihara dan pertahankan. Untuk faktorfaktor yang dinilai telah menjadi kekuatan selayaknya untuk dipelihara dan dipertahankan dikarenakan hal tersebut sangat berpengaruh terhadap eksistensi usaha. Adanya visi, misi, konsep, semangat dan anggaran menjadi modal yang besar dalam pengembangan usaha. Jika faktor ini menurun maka akan menggeser posisi perusahan ke kuadran dibawahnya dan artinya perusahaan akan dalam posisi divestasi atau bangkrut. Selain itu, dalam kegiatan kewirausahaan, modal sosial dapat berfungsi sebagai pengungkit berhasilnya kegiatan usaha, karena dalam modal sosial terdapat nilai-nilai kerja sama (Thobias et al. 2013).

Untuk menggeser posisi perusahaan ke kuadran 1, yaitu pada posisi penetrasi dan ekstensifikasi pasar dan produk maka diperlukan upaya-upaya meningkatkan kelemahan menjadi kekuatan dan meminimalisir ancaman dari luar serta memanfaatkan peluang semaksimal mungkin. Strategi yang umum dilakukan adalah melakukan Product Development dan Market Penetration. Posisi perusahaan dapat dilihat dalam Gambar 1. 

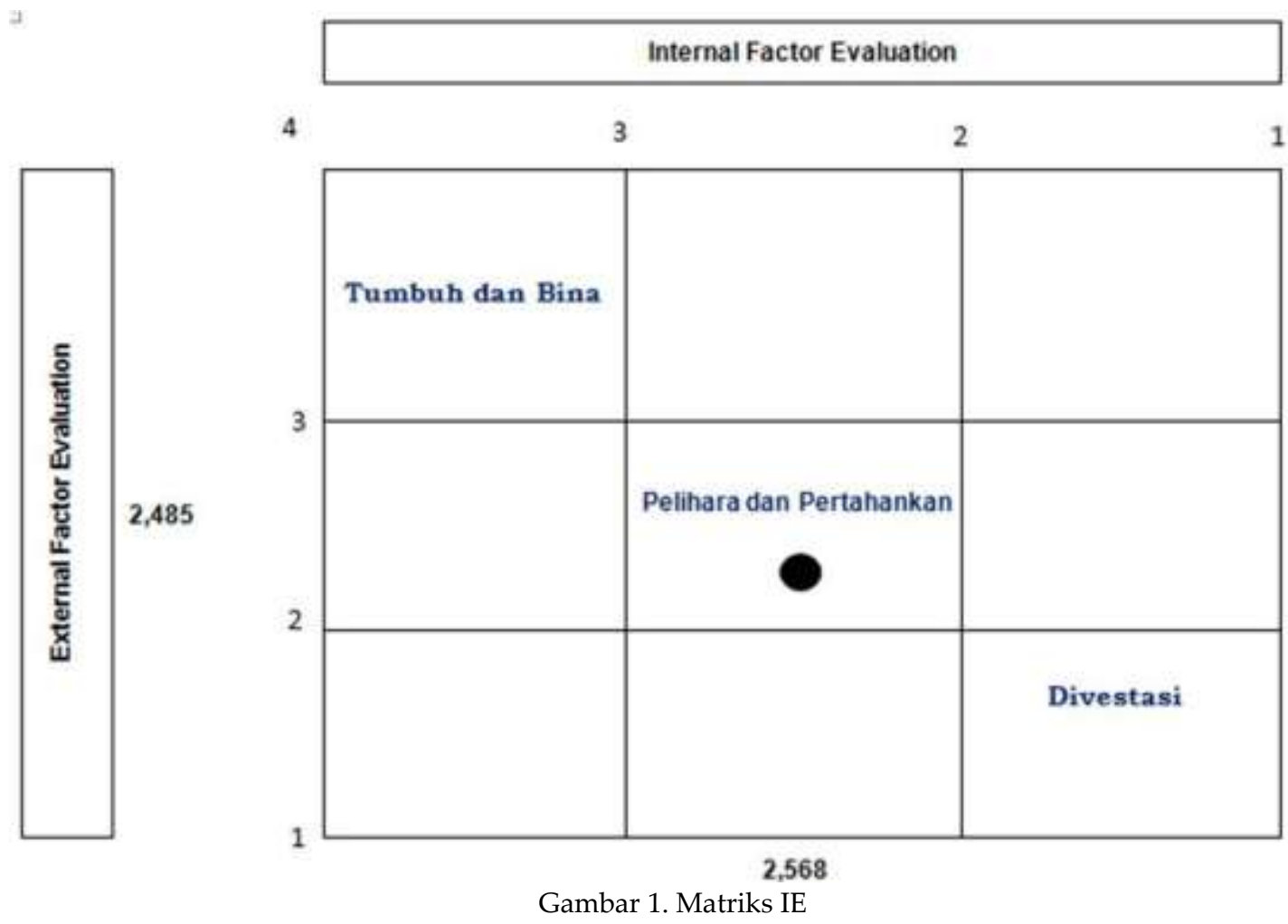

\section{Analisis SWOT}

Untuk menyusun strategi perusahaan perlu diketahui faktor-faktor internal dan eksternal yang menjadi kekuatan, kelemahan, peluang dan ancaman. Selanjutnya dilakukan pencocokan antara masing-masing faktor dan dirumuskan strategi yang dapat menjadi solusi terhadap kondisi tersebut dengan matriks SWOT (Gambar 2).

\section{Strategi SO (Strengths - Opportunities)}

Strategi SO adalah strategi mengoptimalkan kekuatan dengan memanfaatkan semaksimal mungkin peluang yang ada. Kekuatan yang dimiliki adalah spririt, visi, misi, konsep dan anggaran sementara peluang yang ada adalah prospek, nilai produk, adanya mitra kerja, sarana produksi yang dimiliki mitra kerja serta jaringan pasar. Dari faktor-faktor tersebut yang berhubungan dalam memanfaatkan kekuatan untuk memaksimalkan peluang adalah mengoptimalkan anggaran sesuai misi yang dimiliki dengan memanfaatkan semaksimal mungkin peluang yang ada. Strategi yang dapat dikembangkan adalah Fokus, pengembangan produk dan differensiasi (strategi A) dan pengembangan pasar dan penetrasi pasar (strategi B).

\section{Strategi WO (Weaknesses - Opprotunities)}

Strategi WO adalah memanfaatkan peluang dengan mengatasi kelemahan. Peluang yang ada adalah peluang pasar, produk potensial dan mitra kerja, sedangkan kelemahannya adalah stuktur dan alokasi SDM. Untuk memanfaatkan peluang pasar dan produk potensial serta mitra kerja dengan mengatasi kelemahan dalam struktur dan alokasi SDM, maka diperlukan analisis tentang struktur yang tepat agar peluang tersebut dimanfaatkan dengan baik dan juga pembagian kerja yang sesuai dengan fungsi yang dibutuhkan dalam pencapaian rencana. Strategi yang dapat dilakukan adalah Restrukturisasi dan Rekayasa Ulang (strategi C) dan Integrasi Vertikal (strategi D).

\section{Strategi ST (Strengths - Treaths)}

Strategi ini adalah memanfaatkan kekuatan untuk mengurangi ancaman. Kekuatan yang dapat dimanfaatkan adalah adanya anggaran dan spirit serta misi perusahaan untuk mengurangi ancaman dari perusahaan pesaing, produk pesaing dan kontinuitas bahan baku. Strategi yang dapat dilakukan adalah Peningkatan Produk dan Diversifikasi konsentrik (strategi E) serta strategi integrasi vertikal (strategi D).

\section{Strategi WT (Weaknesses - Treaths)}

Strategi ini adalah strategi dalam mengurangi kelemahan dan menghindari ancaman. Kelemahan perusahaan dalam pengambilan kebijakan, struktur, alokasi SDM dan pengendalian serta menghindari ancaman dari perusahaan pesaing dapat dikurangi dan dihindari dengan melakukan strategi restrukturisasi dan rekayasa 


\begin{tabular}{|c|c|c|c|}
\hline \multirow{2}{*}{\multicolumn{2}{|c|}{ Internal }} & Strengths (S) & Weakness (W) \\
\hline & & $\begin{array}{l}\text { 1. Spirit } \\
\text { 2. Anggaran } \\
\text { 3. Visi } \\
\text { 4. Misi } \\
\text { 5. Konsep } \\
\end{array}$ & $\begin{array}{l}\text { 1. Kebijakan } \\
\text { 2. Struktur } \\
\text { 3. SDM } \\
\text { 4. Pengendalian } \\
\text { 5. Alat Ukur Dampak Sosial }\end{array}$ \\
\hline 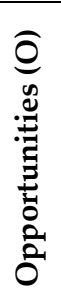 & $\begin{array}{ll}\text { 1. } & \text { Prospek } \\
\text { 2. Nilai Produk } \\
\text { 3. } \text { Mitra } \\
\text { 4. Sarana Produksi } \\
\text { Mitra Kerja } \\
\text { 5. Jaringan Pasar }\end{array}$ & $\begin{array}{l}\text { Strategi A. } \\
\text { Fokus, Pengembangan Produk \& } \\
\text { Differensiasi }(\mathrm{S} 2,4-\mathrm{O} 2,3,4) \\
\text { Strategi B. } \\
\text { Pengembangan Pasar \& Penetrasi } \\
\text { Pasar }(\mathrm{S} 2,4-\mathrm{O} 1,3,5)\end{array}$ & $\begin{array}{l}\text { Strategi C. } \\
\text { Restrukturisasi \& Rekayasa Ulang } \\
\text { (W1,2,3,4,5-O1,2,3,4,5) } \\
\text { Strategi D. } \\
\text { Integrasi Vertikal (ke depan-ke bela- } \\
\text { kang) (W1,4 - O 3,5) }\end{array}$ \\
\hline 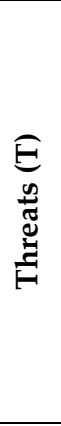 & $\begin{array}{ll}\text { 1. } & \text { Lokasi } \\
\text { 2. } & \text { Penerimaan } \\
\text { Konsumen (Mutu) } \\
\text { 3. Produk pesaing } \\
\text { 4. Perusahaan Pesaing } \\
\text { 5. Kontinuitas Bahan } \\
\text { Baku }\end{array}$ & $\begin{array}{l}\text { Strategi E. } \\
\text { Peningkatan Produk \& Diversifi- } \\
\text { kasi Konsentrik (S2,4-T2,4) } \\
\text { Strategi D. } \\
\text { Integrasi ke depan dan ke belakang } \\
(\mathrm{S} 2,4-\mathrm{T} 1,3,4,5)\end{array}$ & $\begin{array}{l}\text { Strategi C. } \\
\text { Restrukturisasi \& Rekayasa Ulang } \\
(\mathrm{W} 1,2,3,4,5-\mathrm{T} 1,2,3,4) \\
\text { Strategi D. } \\
\text { Integrasi vertikal (ke depan-ke } \\
\text { belakang) (W1,3,4 - T1,2,3,4,5) } \\
\text { Strategi E. } \\
\text { Peningkatan Produk \& Diversifikasi } \\
\text { Konsentrik (W1,4 - T2,4,5) }\end{array}$ \\
\hline
\end{tabular}

Gambar 2. Matriks Analisis SWOT

ulang (strategi C), integrasi vertikal (strategi D) serta strategi peningkatan produk dan diversifikasi konsentrik (strategi E).

\section{Analisis Matriks QSPM}

Berdasarkan hasil analisis SWOT, terdapat beberapa alternatif strategi yang dapat dikembangkan perusahan dalam mencapai tujuan perusahaan. Alternatif strategi tersebut adalah:

Strategi A. Pengembangan Produk dan Differensiasi

Strategi B. Penetrasi Pasar dan Pengembangan Pasar

Strategi C. Restrukturisasi dan Rekayasa Ulang

Strategi D. Integrasi Vertikal (ke depan-ke belakang)

Strategi E. Peningkatan Produk dan Diversifikasi konsentrik

Analisis prioritas alternatif strategi dapat dilihat pada Tabel 1.

Hasil Analisis dengan menggunakan matrik QSP, menunjukan bahwa strategi yang menjadi prioritas pertama dalam pengembangannya adalah Strategi C, yaitu Resrukturisasi dan rekayasa ulang dengan nilai STAS 6,128. Strategi ini adalah strategi dalam melakukan perubahan struktur perusahaan dengan menyesuaikan kondisi saat ini dengan kebutuhan perusahaan dalam pengembangan perusahaan. Penyusunan struktur perusahaan menjadi landasan utama dalam melakukan strategi lainnya. Asumsinya bahwa jika tidak dilakukan perubahan dalam struktur perusahaan maka strategi lainnya tidak dapat dilakukan dengan baik. Restrukturisasi harus disertai dengan re-enginering yaitu analisa fungsi dan tugas untuk masing-masing bagian dalam struktur. Analisis ini diperuntukan agar pekerjaan dapat efektif dan efisien.

Prioritas selanjutnya adalah strategi A, pengembangan produk dan differensiasi. Strategi ini memiliki STAS 5,994, berperan dalam menganalisis produk dan mengembangkan produk potensial. Produk yang dihasilkan haruslah memiliki ciri khas sendiri sebagai keunggulan dari perusahaan-perusahaan sejenis yang menjadi pesaing dalam pengembangan usaha. Dukungan pengadaan sarana, prasarana dan juga teknologi produksi yang tepat dalam mengembangkan produk juga perlu dilakukan dengan teliti. Peran litbang dalam hal ini menjadi sangat penting. Kemampuan litbang dalam melakukan analisis menjadikan salah satu penentu dalam keberhasilan dalam pencapaian tujuan.

Prioritas Ketiga adalah strategi B, penetrasi pasar dan pengembangan pasar. Nilai STAS Strategi ini adalah 5,826. Strategi ini dapat diartikan bahwa penetrasi pasar dan juga pengembangan pasar dilakukan setelah pengembangan produk dilakukan. Penetrasi pasar dilakukan dengan melakukan promosi yang lebih intensif 
dan lebih gencar. Media promosi tidak hanya menggunakan media cetak akan tetapi juga menggunakan media elektronik dan juga $e$ commerce. Dalam prakteknya dapat memanfaatkan jasa layanan pengembangan e-commerce. Promosi juga mengutamakan differensiasi dari keunggulan produk-produk yang dikembangkan. Selanjutnya pengembangan pasar. Penetapan segmen, target dan positioning produk menjadi dasar dalam pengembangan pasar. Survei pasar dilakukan untuk mendapatkan informasi dalam melakukan STP dan juga promosi.

Prioritas keempat yaitu strategi D, integrasi vertikal (ke depan-ke belakang). Nilai STAS strategi ini adalah 5,718. Strategi ini dikembangkan dengan tujuan terbangunnya supply chain dan jaringan kerja sama dengan mitra, meningkatkan daya saing perusahaan dan juga mengurangi resiko ketidakpastian atas bahan baku dan pasar.
Adanya kemampuan dalam mengontrol supply barang, sistem distribusi dan pemasaran menjadikan keunggulan perusahaan dan juga efektivitas waktu dan efisiensi biaya. Integrasi dilakukan dengan membangun kerja sama dengan mitramitra potensial yang pada akhirnya akan membentuk supply chain produk.

Prioritas terakhir adalah strategi E, peningkatan produk dan diversifikasi konsentrik dengan nilai STAS 5,711. Peningkatan produk dinilai perlu dilakukan dengan melakukan perbaikan dan peningkatan mutu produk. Selain itu, analisis harga dan sistem pendistribusian perlu dievaluasi dalam rangka meningkatkan daya saing produk dan perusahaan. Tujuan dari strategi ini adalah mening-katkan daya saing produk. Dengan meningkatnya daya saing produk maka diasumsikan akan meningkatkan permintaan pasar dan volume penjualan.

Tabel 1. Analisis Matriks QSPM

\begin{tabular}{|c|c|c|c|c|c|c|}
\hline \multirow[b]{2}{*}{ No. } & \multirow[b]{2}{*}{ Uraian } & \multicolumn{5}{|c|}{ Alternatif Strategi } \\
\hline & & $\begin{array}{c}\text { A } \\
\text { TAS }\end{array}$ & $\begin{array}{c}\text { B } \\
\text { TAS }\end{array}$ & $\begin{array}{c}\text { C } \\
\text { TAS }\end{array}$ & $\begin{array}{c}\text { D } \\
\text { TAS }\end{array}$ & $\begin{array}{c}\text { E } \\
\text { TAS }\end{array}$ \\
\hline \multicolumn{7}{|c|}{ I. Kekuatan } \\
\hline 1 & Spirit Perusahaan & 0,266 & 0,296 & 0,289 & 0,273 & 0,281 \\
\hline 2 & Anggaran & 0,335 & 0,327 & 0,357 & 0,283 & 0,283 \\
\hline 3 & Visi Perusahaan & 0,280 & 0,273 & 0,300 & 0,286 & 0,245 \\
\hline 4 & Misi Perusahaan & 0,293 & 0,286 & 0,300 & 0,293 & 0,286 \\
\hline \multirow[t]{2}{*}{5} & Konsep Kewirausahaan Sosial & 0,299 & 0,328 & 0,320 & 0,313 & 0,269 \\
\hline & Jumlah & 1,472 & 1,510 & 1,566 & 1,449 & 1,365 \\
\hline \multicolumn{7}{|c|}{ II. Kelemahan } \\
\hline 1 & Kebijakan Perusahaan & 0,277 & 0,248 & 0,342 & 0,248 & 0,284 \\
\hline 2 & Struktur Perusahaan & 0,266 & 0,273 & 0,418 & 0,243 & 0,251 \\
\hline 3 & Sumber Daya Manusia & 0,249 & 0,257 & 0,328 & 0,235 & 0,221 \\
\hline 4 & Sistem Pengendalian & 0,253 & 0,267 & 0,320 & 0,293 & 0,286 \\
\hline \multirow[t]{2}{*}{5} & Alat Ukur Dampak Sosial & 0,254 & 0,247 & 0,215 & 0,338 & 0,312 \\
\hline & Jumlah & 1,299 & 1,291 & 1,622 & 1,357 & 1,354 \\
\hline \multicolumn{7}{|c|}{ III. Peluang } \\
\hline 1 & Prospek & 0,340 & 0,340 & 0,295 & 0,378 & 0,317 \\
\hline 2 & Nilai Produk & 0,363 & 0,338 & 0,288 & 0,280 & 0,387 \\
\hline 3 & Mitra Kerja & 0,281 & 0,274 & 0,261 & 0,307 & 0,274 \\
\hline 4 & Sarana Produksi & 0,288 & 0,275 & 0,281 & 0,254 & 0,241 \\
\hline \multirow[t]{2}{*}{5} & Jaringan Pasar & 0,340 & 0,371 & 0,300 & 0,371 & 0,355 \\
\hline & Jumlah & 1,611 & 1,598 & 1,425 & 1,590 & 1,575 \\
\hline \multicolumn{7}{|c|}{ IV. Ancaman } \\
\hline 1 & Lokasi & 0,517 & 0,347 & 0,354 & 0,310 & 0,347 \\
\hline 2 & Penerimaan Konsumen & 0,310 & 0,303 & 0,268 & 0,239 & 0,324 \\
\hline 3 & Produk Pesaing & 0,281 & 0,294 & 0,281 & 0,254 & 0,248 \\
\hline 4 & Perusahaan Pesaing & 0,281 & 0,300 & 0,274 & 0,307 & 0,287 \\
\hline \multirow[t]{3}{*}{5} & Kontinuitas Bahan Baku & 0,225 & 0,183 & 0,338 & 0,211 & 0,211 \\
\hline & Jumlah & 1,613 & 1,427 & 1,514 & 1,322 & 1,417 \\
\hline & STAS & 5,994 & 5,826 & 6,128 & 5,718 & 5,711 \\
\hline
\end{tabular}

Keterangan: - TAS : Total Attractiveness Score

- STAS : Sum Total Attractiveness Score 


\section{Implikasi Manajerial}

Prioritas strategi yang dihasilkan menunjukkan kemampuan setiap strategi dalam memanfaatkan kekuatan dan peluang untuk mengurangi kelemahan dan ancaman dari luar. Masing-masing strategi memiliki kelebihan dan kekurangan dalam menyelesaikan setiap permasalah yang dihadapi. Dengan demikian perusahan tidak dapat menetapkan satu strategi untuk menyelesaikan seluruh permasalahan atau tantangan yang dihadapi perusahaan. Hal ini berimplikasi bahwa semua strategi tersebut dapat dilaksanakan secara bersama-sama atau tersendiri, tergantung pada tujuan spesifik yang ingin dicapai, kemampuan dan kondisi sumber daya yang dimiliki oleh perusahaan. Begitu juga waktu pencapaian akan ditentukan oleh ketersediaan sumber daya dan kemampuan perusahaan dalam melakukan penyesuaian terhadap kondisi yang ada. Oleh karenanya pelaksanaan perencanaan strategis perlu dilaksanakan secara terpadu dan bertahap. Berikut ini adalah implikasi terhadap sistem manajerial dalam mengembangkan kewirausahaan sosial sesuai kondisi internal dan eksternal perusahaan dan tindakan-tindakan yang perlu dilakukan dalam pencapaian tujuan dengan melakukan alternatif-altenatif strategi.

Restrukturisasi dan Rekayasa ulang bertujuan agar terbangunnya struktur organisasi yang sesuai dengan misi dan kebutuhan perusahaan dengan harapan berfungsinya struktur organisasi dalam bidang, manajerial, penelitian dan pengembangan, pemasaran, administrasi, keuangan, produksi, gudang dan distribusi. Strategi ini dijalankan dengan melakukan evaluasi kinerja, perubahan struktur organisasi dan penetapan kebijakan struktur, serta mengalokasikan staf baru dari internal ataupun merekrut tenaga dari luar.

Fokus, Pengembangan Produk dan Diferensiasi, bertujuan agar tercipta produk-produk unggulan yang memiliki daya saing. Dengan demikian diharapkan perusahaan memiliki produk-produk dari daerah yang memiliki mutu baik dan dapat diterima di pasaran, adanya berbagai jenis turunan produk dari bahan baku yang sama, produk yang dihasilkan memiliki ciri khas masing-masing daerah dan menjadi keunggulan dalam persaingan. Hasil tersebut bisa didapatkan dengan melakukan kajian produk berdasarkan karakteristik produk, ketersediaan bahan baku, ketersediaan tenaga kerja, kemam-puan memproduksi/skill, ketersediaan sarana prasarana dan teknologi, kesesuaian dan kemampuan penyerapan pasar, penetapan produk yang menjadi unggulan dari berbagai produk yang ada, penyediaan sarana, prasarana dan teknologi termasuk didalamnya tempat produksi, SDM, alat produksi, sarana penyimpanan dan alat distribusi.

Pengembangan Pasar dan Penetrasi Pasar. Tujuan dari strategi ini adalah terbangunnya pasarpasar produk potensial yang berkelanjutan. Hasil yang diharapkan dari strategi ini adalah adanya kerja sama pemasaran produk di lokal daerah, bertambahnya pasar potensial di daerah, meningkatnya omset pasar. Aktivitas yang dapat dilakukan dalam mencapai tujuan tersebut adalah penyiapan tools promosi (leaflet, brosur, booklet, e-commerce \& media sosial), Identifikasi pasar potensial, melakukan STP (segmenting, targeting dan positioning) sesuai hasil kajian litbang, promosi melalui media cetak dan elektronik, melakukan promosi kepada mitra potensial dengan melakukan penyebaran media promosi, telemarketing dan pertemuan, negosiasi kerja sama, kesepakatan kerja sama pemasaran, terlibat dalam pameran, terlibat dalam workshop, tergabung dalam assosiasi, seperti pangan organik, pengrajin, rotan, batik dan lain-lain.

Integrasi vertikal (ke depan dan ke belakang). Tujuan dari strategi ini adalah terbangunnya supply chain dan jaringan kerja sama dengan mitra kerja, menambah daya saing perusahaan dan mengurangi resiko ketidakpastian. Hasil yang diharapkan dari strategi ini adalah adanya kerja sama dengan supplier product, kerjasama distribusi barang, kerja sama pemasaran, kerja sama dengan investor, baik individu maupun organisasi, kerja sama dengan organisasi sejenis yang bersifat komplemen dan saling menguntungkan, kerja sama dengan lembaga Litbang seperti Perguruan Tinggi, kerja sama dengan pemerintah terkait. Kegiatan yang dapat dilakukan diantaranya adalah melakukan identifikasi supplier potensial, identifikasi jaringan distribusi potensial, identifikasi pasar potensial, identifikasi investor potensial seperti para pensiunan dan pemodal, negosiasi kerja sama, membangun kesepakatan kerja sama.

Peningkatan Produk dan Diversifikasi. Tujuan dari strategi ini adalah meningkatkan daya saing produk dengan hasil yang diharapkan adalah 
munculnya kebutuhan produk-produk baru sebagai peluang bisnis baru, bertambahnya mitra kerja dari masyarakat (bertambahnya dampak sosial ekonomi), perbaikan mutu produk meliputi fungsi produk, harga produk dan waktu distribusi produk dan pelayanan, meningkatnya permintaan produk, munculnya peluang bisnis baru, menambah peluang investasi bagi pemodal khususnya para pensiunan atau pemodal internal ataupun bagi pemodal umum. Tujuan ini dapat dicapai dengan melakukan kegiatan kajian produk dengan melakukan survei pasar, analisis produk (fungsi, harga dan distribusi serta pelayanan), pengembangan produk, identifikasi peluang baru berdasarkan pasar yang telah terbentuk, analisis kebutuhan pasar terhadap potensi produk baru, kajian terhadap peluang pengem-bangan produk dengan memanfaatkan mitra yang ada atau membuka wilayah dengan sistem dan supply chain baru, pengembangan bisnis baru dengan mitra lama dan mitra baru.

\section{KESIMPULAN}

1. Faktor-faktor internal yang menjadi kekuatan perusahan adalah spirit perusahaan, anggaran, visi, misi dan konsep. Faktor internal yang merupakan kelemahan perusahaan adalah kebijakan, struktur perusahaan, mutu sumber daya manusia, sistem pengendalian, alat ukur dampak sosial. Faktor-faktor eksternal yang menjadi peluang perusahaan adalah prospek pengembangan kewirausahaan sosial, nilai produk, mitra kerja, sarana dan prasarana produksi mitra kerja dan jaringan pasar. Faktor eksternal yang menjadi ancaman perusahaan adalah lokasi, penerimaan konsumen, produk pesaing, perusahaan pesaing dan kontinuitas bahan baku,

2. Alternatif-alternatif strategi yang dapat dikembangkan berdasarkan SWOT adalah Strategi A. Fokus, Pengembangan Produk dan Diferensiasi, Strategi B. Penetrasi Pasar dan Pengembangan Pasar, Strategi C. Restrukturisasi dan Rekayasa Ulang, Strategi D. Integrasi Vertikal (ke depan-ke belakang), Strategi E. Peningkatan Produk dan Diversifikasi.
3. Prioritas strategi pengembangan kewirausa-haan sosial PT BSK adalah (1) Strategi C, (2) Strategi A, (3) Strategi B, (4) Strategi D dan (5) Strategi E.

\section{DAFTAR PUSTAKA}

Bornstein, D. 2004. How to Change the World: Social Entrepreneurs and the Power of New Ideas. Oxford University Press, New York.

David, F.R. 2004. Konsep Manajemen Strategis. Edisi Bahasa Indonesia. Buku Asli Concepts of Strategic Management $7^{\text {th }}$ Edition. Alih Bahasa oleh Alexander Sindoro. Prenhallindo, Jakarta.

Krueger, N. 1993. The Impact of Prior Entrepreneurial Exposure on Perceptions of New Venture Feasibility and Desirability. Entrepreneurial Theory Practice, 18(1): 5-21.

Hubeis, M. dan M. Najib 2008. Manajemen Strategik dalam Pengembangan Daya Saing Organisasi. PT Elex Media Komputindo, Jakarta.

Ismawan, B. 2010. Social Entrepreneurship is The Bina Swadaya Way-Suatu Catatan Diskusi. http://sinergi-indonesia.org/index. php/socialentrepreneurship-the-bina-swadaya-catatandiskusi/. (Agustus 2010).

Lee, S.H. \& P.K. Wong. 2004. An Exploratory Study of Technopreneurial Intentions: A Career Anchor Perspective. Journal of Business Venturing, 19(1): 7-28.

Rangkuti, F. 2005. Analisis SWOT Teknik Membedah Kasus Bisnis. PT. Gramedia Pustaka Utama, Jakarta.

Priyanto S.H. 2009. Mengembangkan Pendidikan Kewirausahaan di Masyarakat. Jurnal PNFI, 1 (1): 57-82.

Tan, W.L., J. Williams, dan T.M. Tan. (2005). 'Defining the 'Sosial' in 'Sosial Entrepreneurship': Altruism and Entrepreneurship'. International Entrepreneurship and Management Journal 1, pp 353-365.

Thobias, E., A.K. Tungka, J.J. Rogahang. 2013. Pengaruh Modal Sosial terhadap Perilaku Kewirausahaan (Suatu studi pada pelaku usaha mikro kecil menengah di Kecamatan Kabaruan Kabupaten Kepulauan Talaud). Journal ACTA DIURNA, 2 (2): 1-12. 